\title{
Radiotracers, tritium labelling of neuropeptides
}

\author{
Géza Tóth, ${ }^{\text {a* }}$ Jayapal Reddy Mallareddy, ${ }^{a}$ Fanni Tóth, ${ }^{a}$ Andrzej W. Lipkowski, \\ and Dirk Tourwéc \\ ${ }^{a}$ Biological Research Center, H-6726 Szeged, Temesvári krt 62, Hungary \\ ${ }^{b}$ Mossakowski Medical Research Center of Polish Academy of Sciences, \\ P-02106 Pawinskiego 5, Warsaw, Poland \\ ${ }^{c}$ Department of Organic Chemistry, Vrije Universiteit Brussel, Pleinlaan 2, \\ B-1050, Brussels, Belgium \\ E-mail:geza@brc.hu
}

\section{Dedicated to Professor Ferenc Fülöp on the occasion of his $60^{\text {th }}$ birthday}

\begin{abstract}
Tritium labelled endomorphins (Tyr-Pro-Trp-Phe- $\mathrm{NH}_{2}$, EM1, Tyr-Pro-Phe-Phe-NH 2 , EM2) and their analogs, Angiotensin-IV (Val- Tyr-Ile-His-Pro-Phe) and its analogs, Neuromedin N (LysIle-Pro-Tyr-Ile-Leu) and a new nociceptin analog (Phe-Phe-Gly-pFPhe-Thr-Gly-Aib-Arg-LysSer-Ala-Arg-Lys-Arg-Lys-Asn-Gln- $\mathrm{NH}_{2}$ ) and Substance P analogs (Arg-Pro-Lys-Pro-Gln-GlnPhe-Phe-Gly-Leu-Nle-NH ${ }_{2}$, Arg-Pro-Lys-Pro-Gln-Gln-Phe) were synthesized by catalytic dehalogenation or saturation of the precursor peptides with tritium gas. The specific radioactivity of the neuropeptides is high, ranging from $0.6 \mathrm{TBq} / \mathrm{mmol}$ to $2.8 \mathrm{TBq} / \mathrm{mmol}$. The labelled peptides were characterized by radioreceptor binding assays and used in mapping their metabolic pathway using rat brain membrane preparation.
\end{abstract}

Keywords: Tritium label, endomorphins, angiotensin IV, neuromedin-N, nociceptin, substance P

\section{Introduction}

Isotope labelling is an essential tool for determining the fate of any given organic compound in a chemical or biochemical system. $\mathrm{H}, \mathrm{C}, \mathrm{O}, \mathrm{N}$ and $\mathrm{P}$ are important elements in the biological systems. Since almost all organic compounds contain hydrogen and carbon, these isotopes are by far the most widely used in chemical and biological tracer studies. Tritium has become more important for several reasons: the half life of tritium (12.37 year) is relatively high and tritium labelled compounds have a high specific radioactivity. The compounds with high specific radioactivity are useful for many biological investigations. Tritium labelling chemistry is often 
simple and labelling can be usually accomplished very late in the overall synthesis, thus minimizing the radiochemical handling required. Tritium is a beta emitter with low energy and low toxicity. The most advantageous property of tritiated compounds as tracers is due to the high stability of the tritium label under experimental conditions. The most stable label is the tritium attached $\mathrm{C}$ atom. Labile-, acid labile-, alkali labile- and bio labile tritium can be in the labelled compounds. There are two basic approaches for introducing tritium into organic molecules: exchange labelling and synthetic tritiation methods. ${ }^{1,2}$ The significant factors in the methods used are the availability of the radioactive materials $\left({ }^{3} \mathrm{H}\right.$ gas, $\mathrm{C}^{3} \mathrm{H}_{3} \mathrm{I}$, tritiated metal hydrides, tritiated water) and the precursors. The preparations are usually carried out on micro chemical scale and if possible the tritium atoms are incorporated in the compound in the last step. The choice of the solvent is essential in the reaction mixture. A solvent without labile hydrogen was generally used to get a higher specific radioactivity of the product. $\mathrm{PdO} / \mathrm{BaSO}_{4}, \mathrm{PdO}$ and $\mathrm{Pd} / \mathrm{C}$ catalysts are generally used in tritium labelling.

In the past decade we have designed and synthesized several new tritium labelled neuropeptides. ${ }^{2}$ Investigation of neuropeptide receptors requires biologically active peptides containing radioactive, fluorescent, or affinity labels. Receptor studies, in vitro biochemical radioligand receptor binding assays, radio immunoassays are usually based on peptides labelled with ${ }^{3} \mathrm{H}$ or ${ }^{125} \mathrm{I}$. Tritium label in radioactive peptides is favorable because the structure of the radioactive material is the same as the parent peptide, so the biological activity is identical.

Tritium labelled peptides can be prepared by: 1. Synthesis of neuropeptides using tritiated amino acids (solid phase peptide synthesis); 2. Catalytic isotope exchange reactions using ${ }^{3} \mathrm{H}_{2} ; 3$. Synthesis of ${ }^{3} \mathrm{H}$-neuropeptides using precursor peptides (post synthetically modified derivatives, synthetic precursors for tritiation); 4. Derivatization of neuropeptides by tritiated methyl iodide (see Figure 1.).

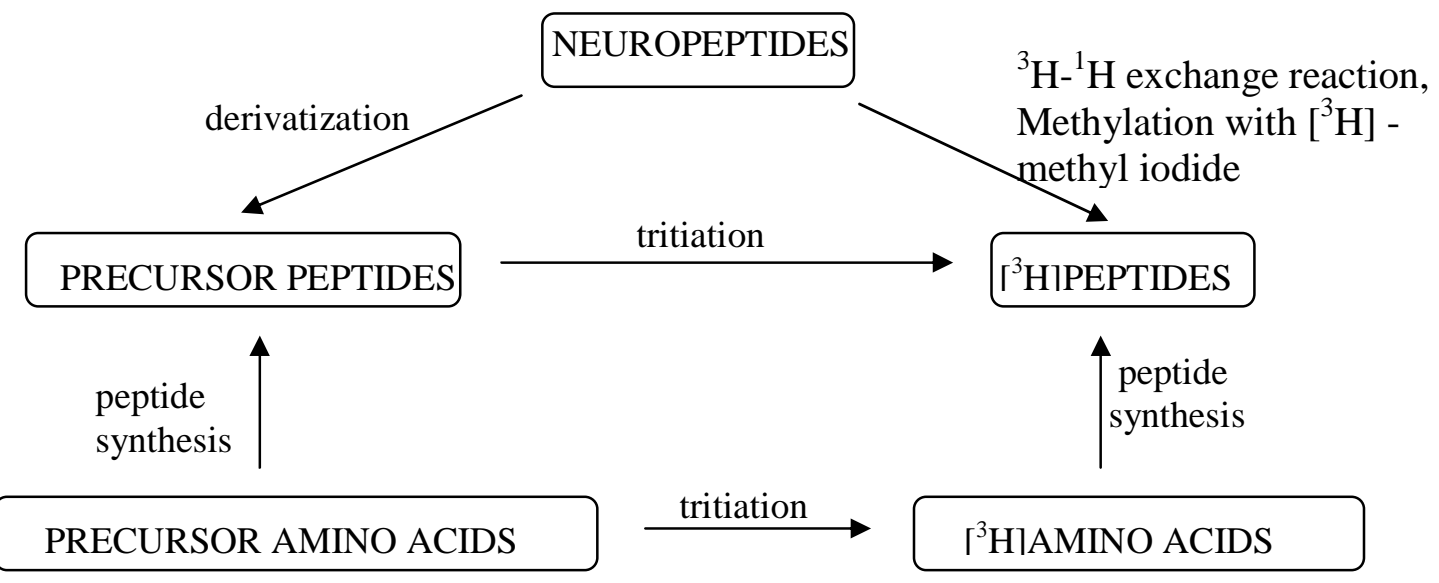

Figure 1. Different synthetic routes for tritiated neuropeptides.

The most frequently used precursor amino acids are halogenated aromatic amino acids or amino acids containing double or triple bond for the synthesis of precursor peptides (see Figure 
2.). Boc- and Fmoc-amino acids can be also used for the synthesis of precursor peptides. This paper describes the tritium labelling of endomorphins and their analogs, angiotensin IV derivatives, neuromedin $\mathrm{N}$ and a new nociceptin agonist, a substance $\mathrm{P}$ analog and substance $\mathrm{P}$ (1-7), and their usage as a tool in research.

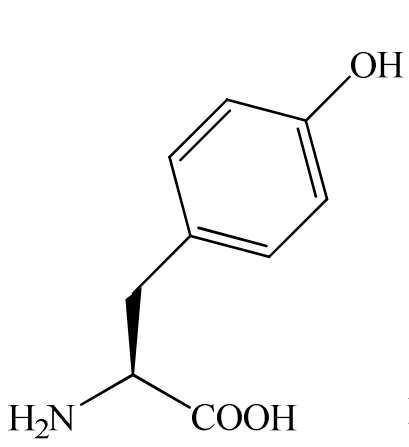

a

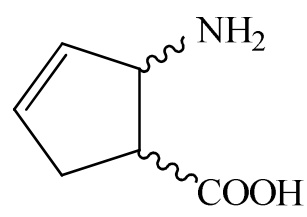

e

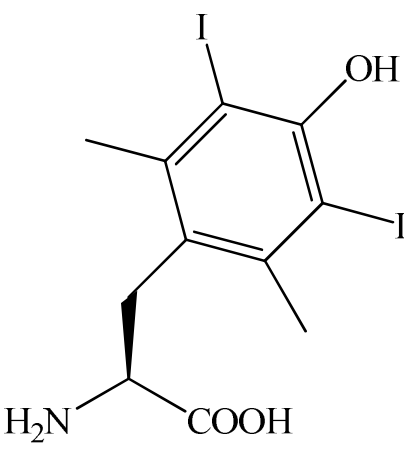

b<smiles>NC1CCC=CC1C(=O)O</smiles>

f

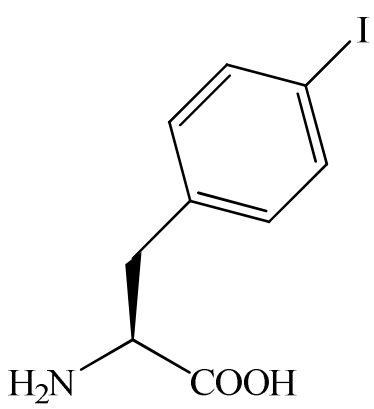

$\mathrm{c}$

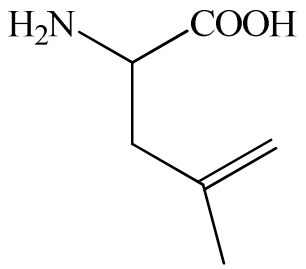

g

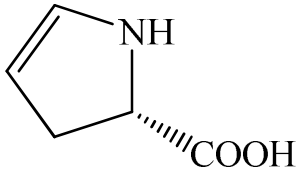

d<smiles>C#CCC(N)C(=O)O</smiles>

$\mathrm{h}$

Figure 2. Precursor amino acids for the synthesis of tritiated peptides: a) 3, 5-diiodo-tyrosine; b) 3, 5-diiodo-2, 6-dimethyl-tyrosine; c) p-iodo-phenylalanine; d) 3, 4-dehydro-proline; e) 2aminocyclopentenecarboxylic acid; f) 2-aminocyclohexenecarboxylic acid.

\section{Results and Discussion}

\section{Radioactive labelling of endomorphins}

The investigation of neuropeptide receptors requires biologically active peptide analogs containing radioactive, fluorescent, chemiluminescent (photo) affinity or other chemically reactive marker groups. Radioisotopes are the most frequently used marker for peptides. In vitro biochemical analysis are usually based on peptides labelled with ${ }^{3} \mathrm{H}$ and ${ }^{125} \mathrm{I}$. Tritium is a soft beta-emitting radionuclide. One milliatom tritium represents a radioactivity of $1.1 \mathrm{Tbq} / \mathrm{mmol}$ $(28.6 \mathrm{Ci} / \mathrm{mmol})$, thus tritium incorporation is suitable for studies in subnanomolar concentration of peptides.

Among other possibilities (isotope exchange reactions, chemical or enzymatic synthesis of peptides from tritiated amino acids, derivatization of the neuropeptides by ${ }^{3} \mathrm{H}$-methyl iodide or 
reductive methylation of ${ }^{3} \mathrm{H}$-formaldehyde), synthesis of tritiated neuropeptides using synthetic precursors containing unsaturated or halogenated amino acids is a widely used method ${ }^{2}$ (Figure 1.). The most popular precursor amino acids are 3,4-dehydro-proline; 4,5-dehydro-leucine; 3, 5diiodo-tyrosine; $\mathrm{p}$-iodo-phenylalanine. The labels can be introduced to other specific amino acids in the peptides too (see Figure 2.).

In the last twelve years several tritiated endomorphin isotopomers and several radioactive endomorphin analogs were designed and synthesized ${ }^{3,4}$ (see Figure 3. and Table 1.). The new tritiated endomorphins were used as radioligands in binding studies, homologue or heterologue displacement studies to characterize the new endomorphin derivatives. ${ }^{3,5,6}$ Furthermore tritiated ligands were used in degradation studies ${ }^{4}$ of endomophins and their new analogs ${ }^{7-11}$ or for autoradiography.

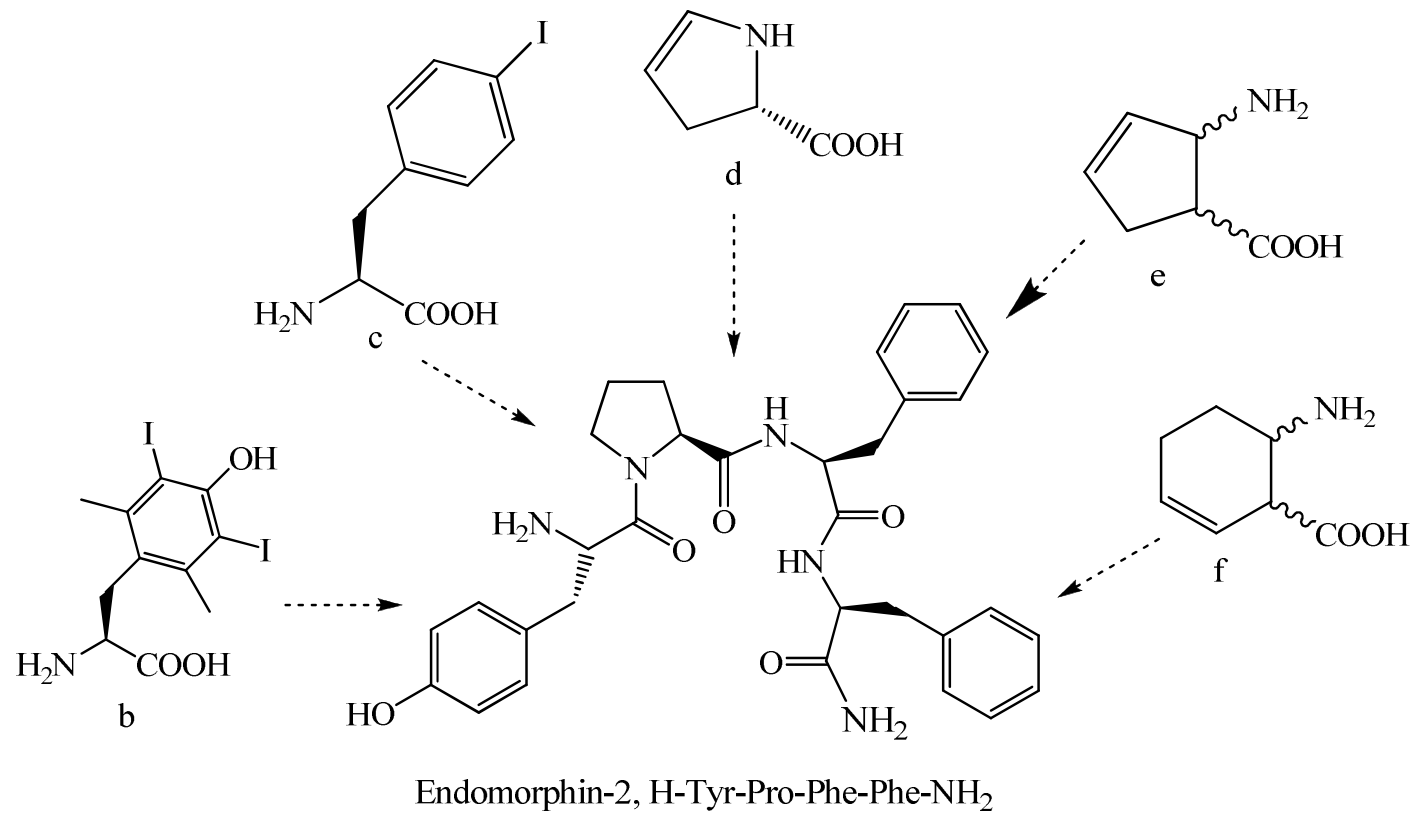

Figure 3. Precursor endomorphin-2 derivatives.

The most promising new analogs were also labelled by tritium in our laboratory. The Dmt ${ }^{1}$ endomorphin-2 was more active compared to endomorphin- 2 towards $\mu$ - and $\delta$-opioid receptors. The tritium labels were introduced on Dmt or Pro using 3, 5-diiodo-Dmt or 3',4'dehydro-proline containing precursors respectively using tritium gas and a $\mathrm{PdO} / \mathrm{BaSO}_{4}$ as catalyst. ${ }^{11}$ Novel endomorphin analogs containing alicyclic $\beta$-amino acids were prepared in tritiated form as well. The precursor peptides containing cis-2-aminocyclopentenecarboxylic acid ( $\triangle \mathrm{Acpc}$ ) or cis-2aminocyclohexenecarboxylic acid $(\Delta \mathrm{Achc})$ were saturated by tritium gas in the presence of a $\mathrm{Pd} / \mathrm{BaSO}_{4}$ catalyst. $^{7-10}$ 


\section{${ }^{3} \mathrm{H}$-Angiotensin IV and its new analogs}

Angiotensin IV (H-Val-Tyr-Ile-His-Pro-Phe-OH) is a physiologically active metabolite of Angiotensin-II in the renin-angiotensin system (RAS). It is suggested that it may exert its effects through binding to AT4 receptors also denoted as Insulin Regulated Amino Peptidase (IRAP). ${ }^{12,13}$ The degradation of angiotensin IV is facilitated by different proteases. ${ }^{14}$ We reported earlier that $\beta$-homo-amino acid containing analog (H-(R)- $\beta^{2} \mathrm{hVal}-\mathrm{Tyr}-\mathrm{Ile}$-His-Pro- $\beta^{3} \mathrm{hPhe}-\mathrm{OH}$, AL-11) is a potent, selective and stable angiotensin IV antagonist in which the (R)- $\beta^{2} h$ Val is responsible for the stability and the $\beta^{3}$ hPhe for the selectivity. A new analog, AL- $40^{15}(\mathrm{H}-(\mathrm{R})-$ $\beta^{2} \mathrm{hVal}$-Tyr-Ile-Aia-Gly- $\beta^{3} \mathrm{hPhe}-\mathrm{OH}$, Aia: 4-amino-1, 2, 4, 5-tetrahydro-indolo [2, 3-c]-azepin3 -one) in which the His-Pro dipeptide residue is replaced by a constrained Trp analog, Aia-Gly. AL-40 has an improved potency compared to AL-11. A new analog containing Nva (norvaline) instead of glycine (IVDE77) has shown promising properties. ${ }^{16}$ The pharmacological profile of recombinant IRAP has already been studied both by radioligand competition binding and enzyme activity inhibition experiments. The angiotensin IV and the two new analogs were labelled by tritium. The structure of the two new precursor peptides is shown in the Table 1. Dehydro-proline ( $\Delta$ Pro) or propargyl-glycine (Pra) amino acids led to the precursor peptides for the labelling of AL-11 and IVDE-77 (see Figure 4.). The specific radioactivity of all angiotensin IV analogs was found to be adequate for radioligand receptor binding assays.<smiles>C#CC[C@H](C(=O)N[C@@H](Cc1ccccc1)C(=O)O)N1Cc2[nH]c3ccccc3c2C[C@H](NC(=O)[C@H](NC(=O)[C@H](Cc2ccc(O)cc2)NC(=O)[C@@H](CN)C(C)C)C(C)CC)C1=O</smiles>

IVDE76<smiles>[3H]C([InH])([IH])C(I)(I)C[C@@H](C(=O)N[C@@H](Cc1ccccc1)C(=O)O)N1Cc2[nH]c3ccccc3c2C[C@H](NC(=O)[C@@H](NC(=O)[C@H](Cc2ccc(O)cc2)NC(=O)[C@@H](CN)C(C)C)C(C)CC)C1=O</smiles>

Figure 4. Synthesis of ${ }^{3} \mathrm{H}-\mathrm{IVDE} 77$. 


\section{${ }^{3}$ H-neuromedin-N (Lys-Ile- ${ }^{3}$ HPro-Tyr-Ile-Leu-OH)}

Neuromedin- $\mathrm{N}$ is a neurotensin like peptide, both peptides are synthesized by a common precursor protein (pro NT/NN) in mammalian brain and intestine. ${ }^{17}$ Neuromedin-N and the precursor peptide were synthesized by incorporating $\Delta$ Pro in the place of Pro. Synthesis of these peptides was performed by Fmoc chemistry using Fmoc-Wang resin. Labelling of neuromedin-N was carried out using the precursor peptide, tritium gas and $\mathrm{PdO} / \mathrm{BaSO}_{4}$ catalyst in $\mathrm{DMF}$. The specific radioactivity of labelled neuromedin- $\mathrm{N}$ was found to be $0.6 \mathrm{TBq} / \mathrm{mmol}$. Until now nobody prepared it in tritiated form, so we used the ${ }^{3} \mathrm{H}$-neuromedin- $\mathrm{N}$ for characterization of radioreceptor binding on membrane preparation of rat brain and rat spinal cord. This work is in progress.

\section{[4- ${ }^{3}$ H Phe $^{1}$-]- pFPhe ${ }^{4}-$ Aib $^{7}$ - Arg $^{14}$-Lys ${ }^{15}$ Nociceptin-NH $2\left({ }^{3}\right.$ H-UFP-112)}

Nociceptin (Phe-Gly-Gly-Phe-Thr-Gly-Ala-Arg-Lys-Ser-Ala-Arg-Lys-Leu-Ala-Asn-Gln-OH) is an endogenous ligand for the nociceptin receptor. UFP-112 (pFPhe ${ }^{4}-\mathrm{Aib}^{7}-\mathrm{Arg}^{14}-\mathrm{Lys}^{15}$ Nociceptin- $\mathrm{NH}_{2}$ ) is a novel potent and long lasting agonist for the NOP receptor. ${ }^{18} \mathrm{H}-\mathrm{UFP}-112$ has been designed as a novel ligand for the nociceptin receptor (NOP) by combining into the same peptide different chemical modifications ( $\mathrm{pFPhe}$ in the first position, $\alpha$-amino-isobuthyric acid (Aib) in the position 7, Arg-Lys in position 14, 15) in order to increase nociceptin potency. The tritiated UFP-112 was prepared. Before the tritiation we used hydrogenation at room temperature, reaction time $60 \mathrm{~min}$ and the crude product was checked by HPLC. The main peak (retention time: $12.7 \mathrm{~min}$ ) was the UFP-112 according to the molecular mass (1939.84), that means there is $\mathrm{F}$ atom in the peptide. The precursor peptide ( $\mathrm{pI} \mathrm{Phe}^{1}-\mathrm{pFPhe}^{4}-\mathrm{Aib}^{7}-\mathrm{Arg}^{14}-\mathrm{Lys}^{15}$ Nociceptin- $\mathrm{NH}_{2}$ ) containing pIPhe and $\mathrm{pFPhe}$ was used for tritiation by tritium gas using PdO (85\% Pd) in DMF at room temperature for $60 \mathrm{~min}$. The same condition was used for tritiation as above in the case of hydrogenation. The crude peptide was purified by RP-HPLC. The purification of the crude labelled peptide was done (see in the experimental part) by HPLC. Specific radioactivity was $0.73 \mathrm{TBq} / \mathrm{mmol}$. The tritiated peptide was stored in liquid nitrogen.

\section{${ }^{3}$ H-Substance-P analogs}

Substance-P (SP, H-Arg-Pro-Lys-Pro-Gln-Gln-Phe-Phe-Gly-Leu-Met-NH2) is the first mammalian tachykinin that acts as a neurotransmitter or a neuromodulator. ${ }^{19}$ Tritiated SP was prepared and used for characterization of tachykinin receptors and new tachykinin analogs. ${ }^{20}$ Previously we reported a SP analog, Nle ${ }^{11}$-SP in tritiated form as a radioligand. ${ }^{21}$ In the original sequence of SP, methionine is in the position 11, methionine can be oxidized, especially if the material is radioactive. The $\mathrm{Nle}^{11}$-SP has a very similar biological activity in comparison with SP; therefore we selected it for tritium labeling using dehydro-proline containing precursor peptide (see in Table 1.). Norleucine is a methionine mimetic and it has been used in opioid and melanotropin research. The new analog does not oxidize hence it is a useful tool in tachykinin research. 
The N-terminal metabolite of SP (Substance-P (1-7)) can bind to a different receptor as compared to SP. SP-(1-7) was synthesized in tritiated form ${ }^{22}$ and it was used to characterize a new receptor. Dehydro-proline containing SP-(1-7) was used as a precursor for the tritium labelling.

Table 1. Tritium labelled neuropeptides

\begin{tabular}{|c|c|c|c|}
\hline no. & Precursor peptides & Labelled peptides & $\begin{array}{c}\text { Specific } \\
\text { radioactivity } \\
(\mathrm{TBq} / \mathrm{mmol})\end{array}$ \\
\hline 1 & H-Dit-Pro-Trp-Phe-NH 2 & $\mathrm{H}^{-}{ }^{\mathbf{3}} \mathbf{H}$-Tyr-Pro-Trp-Phe-NH${ }_{2}$ & 1,53 \\
\hline 2 & 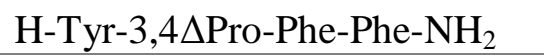 & H-Tyr-3,4 ${ }^{3}$ H-Pro-Phe-Phe- $\mathrm{NH}_{2}$ & 1,88 \\
\hline 3 & H-Dmt-3,4 $\Delta$ Pro-Phe-Phe- $\mathrm{NH}_{2}$ & H-Dmt-3,4- ${ }^{3}$ HPro-Phe-Phe-NH ${ }_{2}$ & 2,87 \\
\hline 4 & $\mathrm{H}-3,5 \mathrm{I}_{2}$ Dmt-Pro-Phe-Phe-NH${ }_{2}$ & H-3,5- ${ }^{3}$ HDmt-Pro-Phe-Phe- $\mathrm{NH}_{2}$ & 1.95 \\
\hline 5 & $\begin{array}{l}\text { H-Tyr-(1S,2R) } \Delta \text { Acpc-Phe-Phe- } \\
\mathrm{NH}_{2}\end{array}$ & $\begin{array}{l}\text { H-Tyr- }(\mathbf{1 S}, 2 \mathbf{2})^{\mathbf{3}} \mathbf{H}-\mathrm{Acpc}-\mathrm{Phe}-\mathrm{Phe}- \\
\mathrm{NH}_{2}\end{array}$ & 1,41 \\
\hline 6 & $\begin{array}{l}\text { H-Tyr-(1S,2R) } \Delta \text { Achc-Phe-Phe- } \\
\mathrm{NH}_{2}\end{array}$ & $\begin{array}{l}\text { H-Tyr- }(\mathbf{1 S}, 2 \mathbf{2})^{\mathbf{3}} \mathbf{H} \text {-Achc-Phe-Phe- } \\
\mathrm{NH}_{2}\end{array}$ & 2,35 \\
\hline 7 & $\begin{array}{l}\text { H-Arg- } \Delta \text { Pro-Lys- } \Delta \text { Pro-Gln- } \\
\text { Gln-Phe -Phe-Gly-Leu-Nle- } \\
\mathrm{NH}_{2}\end{array}$ & $\begin{array}{l}\text { H-Arg- }{ }^{3} \text { HPro-Lys- }{ }^{3} \text { HPro-Gln-Gln- } \\
\text { Phe-Phe-Gly-Leu-Nle-NH }\end{array}$ & 0,84 \\
\hline 8 & $\begin{array}{l}\text { H-Arg- } \Delta \text { Pro-Lys- } \Delta \text { Pro-Gln- } \\
\text { Gln-Phe-OH }\end{array}$ & $\begin{array}{l}\text { H-Arg- }{ }^{3} \text { HPro-Lys- }{ }^{3} \text { HPro-Gln-Gln- } \\
\text { Phe-OH }\end{array}$ & 1,09 \\
\hline 9 & $\begin{array}{l}\text { H-Lys-Ile- } \Delta \text { Pro-Tyr-Ile-Leu- } \\
\mathrm{OH}\end{array}$ & H-Lys-Ile- ${ }^{3}$ HPro-Tyr-Ile-Leu-OH & 0.6 \\
\hline 10 & $\begin{array}{l}\text { H-(R)- } \beta^{2} h \text { Val-Tyr-Ile-His- } \\
\Delta \text { Pro- } \beta^{3} \text { hPhe-OH }\end{array}$ & $\begin{array}{l}\text { H-(R)- } \beta^{2} \text { hVal-Tyr-Ile-His- }{ }^{3} \text { HPro- } \\
\beta^{3} \text { hPhe-OH }\left({ }^{3} \mathrm{H}-\mathrm{AL}-11\right)\end{array}$ & 1,29 \\
\hline 11 & $\begin{array}{l}\text { H-(R)- } \beta^{2} \text { hVal-Tyr-Ile-Aia-Pra- } \\
\text { Phe-OH (IVDE76) }\end{array}$ & $\begin{array}{l}\text { H-(R)- } \beta^{2} \text { hVal-Tyr-Ile-Aia- }{ }^{3} \mathbf{H}-\mathbf{N v a -} \\
\text { Phe-OH (IVDE77) }\end{array}$ & 0.9 \\
\hline 12 & $\begin{array}{l}\mathrm{H}-[4-\mathrm{I}] \text { Phe-Gly-Gly-pFPhe- } \\
\text { Thr-Gly-Aib-Arg-Lys-Ser-Ala- } \\
\text { Arg-Lys-Arg-Lys-Asn-Gln- } \\
\mathrm{NH}_{2}\end{array}$ & $\begin{array}{l}\left.\text { H-[4- }{ }^{3} \mathbf{H}\right] \text { Phe-Gly-Gly-pFPhe-Thr- } \\
\text { Gly-Aib-Arg-Lys-Ser-Ala-Arg- } \\
\text { Lys-Arg-Lys-Asn-Gln-NH } 2 \\
\left({ }^{3} \text { H-UFP112) }\right.\end{array}$ & 0.73 \\
\hline
\end{tabular}

Compounds 1-6 endomorphin analogs; 7-8 Substance P analogs; 9 Neuromedin-N; 10-11 Angiotensin IV analogs; 12 Nociceptin analog. 


\section{Experimental Section}

General. Protected and unprotected amino acids, 4-methylbenzhydrylamine (MBHA), Merrifield resins and coupling reagents were purchased from Calbiochem-Novobiochem or Bachem. Radio-TLC was performed on Silicagel $60 \mathrm{~F}_{254^{-}}$precoated glass plates (Merck) and the radioactive spots were detected by a Berthold LB 2821 flow-through (9.9\% methane/Argon) Geiger-Müller counter. Radio HPLC was performed on a Jasco HPLC instrument, using Vydac 218TP54 column and liquid scintilation detection on a Canberra Packard Radiomatic 505 TR Flow Radiochromatography Detector using the ultima-Flo $\mathrm{M}$ scintillation cocktail. The mobil phase used was consisting of $0.1 \%(\mathrm{v} / \mathrm{v})$ TFA in water and $0.08 \%(\mathrm{v} / \mathrm{v})$ TFA in acetonitrile. Tritiation was carried out in a selfmade vacuum manifold ${ }^{1}$. Tritium gas was purchased from Technobexport, Russia and contained at least 98\% tritium. $\mathrm{PdO} / \mathrm{BaSO}_{4}, \mathrm{PdO}(85 \%)$ were purchased from Merck. The radioactivity of the labelled compounds was measured by TRICARB 2100TR Counter (Canberra-Packard, Perkin Elmer Life Sciences, Boston, MA).

Synthesis of precursor peptides by SPPS and peptide purification. The peptide analogs were synthesized by a manual solid-phase peptide synthetiser ${ }^{10}$ by using Boc protected amino acids and MBHA resin or Merrifield resin to obtain C-terminal amides or carboxylic acid. Peptide chain elongation was carried out by using $\mathrm{N}$-hydroxybenzotrioazole and $\mathrm{N}, \mathrm{N}$ dicyclohexylcarbodiimide coupling agents. Each coupling was monitored by the ninhydrin test. The protective groups were removed with a solution containing 50\% TFA, 48\% DCM, $2 \%$ anisole. Neutralization was performed with a solution of $10 \%$ diisopropyl-ethylamine (DIEA) in DCM. The removal of the peptides from the resin was accomplished with anhydrous HF (10 $\mathrm{mL} / \mathrm{g}$ resin) in presence of anisole $\left(1 \mathrm{~mL} / \mathrm{g}\right.$ resin) and dimethylsulfide $\left(1 \mathrm{~mL} / \mathrm{g}\right.$ resin) at $0^{\circ} \mathrm{C}$ for $60 \mathrm{~min}$. After evaporation of the HF, the resin was washed with diethyl ether to remove the scavengers. Peptides were precipitated with diethyl ether, filtered, extracted with $30 \%$ (v/v) aqueous acetic acid. After lyophilization of the diluted extract, crude peptides were obtained in solid form (yields $75-85 \%$ ). The crude peptides were separated by using semipreparative RPHPLC on Vydac 218TP1010 $\mathrm{C}_{18}$ column. Identities of all compounds were confirmed by MALDI-TOF spectrometry and their purities were found to be over 98\%. Neuromedin-N (LysIle-Pro-Tyr-Ile-Leu-OH) and neuromedin-N precursor (Lys-Ile- $\Delta$ Pro-Tyr-Ile-Leu-OH) were obtained from Patrycja Kleczkowska (Mossakowski Medical Research Center of Polish Academy of Sciences, Warsaw, Poland.) The angiotensin IV analog (H-(R)- $\beta^{2}$ hVal-Tyr-Ile-HisPro- $\beta^{3} h$ Phe-OH) and its precursor (H-(R)- $\beta^{2} h$ Val-Tyr-Ile-Aia-Pra- $\beta^{3} h$ Phe-OH using propargylglysine (Pra )) were obtained from Isabelle Van den Eynde (Department of Organic Chemistry, Vrije Universiteit Brussel, Belgium), FPhe ${ }^{4}-\mathrm{Aib}^{7}-\mathrm{Arg}^{14}$-Lys ${ }^{15}$ Nociceptin- $\mathrm{NH}_{2}$ and its precursor ( $\mathrm{pIPhe}^{1} \mathrm{pFPhe}^{4}-\mathrm{Aib}^{7}$-Arg ${ }^{14}-\mathrm{Lys}^{15}$ Nociceptin- $\mathrm{NH}_{2}$ ) were obtained from Remo Guarreni (University of Ferrara, Italy). 


\section{Tritium labelling. General procedure}

The precursor peptide $(2 \mathrm{mg})$ dissolved in $1 \mathrm{~mL}$ of dimethylformamide in the presence of $1.5 \mu \mathrm{L}$ of triethylamine (in the case of iodo-containing precursors) and $10 \mathrm{mg} \mathrm{PdO} / \mathrm{BaSO}_{4}$ catalyst was added and the reaction vessel was connected to the tritium manifold ${ }^{2}$. Tritium gas $555 \mathrm{GBq}(15$ $\mathrm{Ci}$,) was liberated by heating from uranium tritide and it was introduced into the reaction vessel. The reaction mixture was stirred by a magnetic stirrer at room temperature for 1-2 hours. The unreacted tritium was removed by absorption on pyrophoric uranium. The vessel was removed from the tritium manifold to work up the crude mixture. The catalyst was filtered off using Whatmann GF/C glass-fiber filter. Labil tritium was removed by repeated evaporation with ethanol/water $1: 1$. The crude product was purified by HPLC to give a radioactive purity of $95 \%$. The quantitative analysis of the pure, labelled peptides was performed by RP-HPLC via a UV detector, using a calibration curve prepared by unlabelled standard peptides to obtain the quantity of the radioactive peptide and the total radioactivity of the product was measured by liquid scintillation counting. The specific radioactivity of the labelled peptides was calculated from these data, see Table 1. The tritiated peptides were dissolved in ethanol and were stored at a concentration of $37 \mathrm{MBq} / \mathrm{mL}$ in liquid nitrogen.

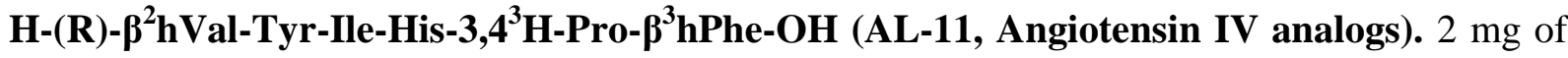
$\mathrm{H}-(\mathrm{R})-\beta^{2} \mathrm{hVal}-\mathrm{Tyr}-\mathrm{Ile}-\mathrm{His}-\Delta$ Pro- $\beta^{3} \mathrm{hPhe}-\mathrm{OH}$ was dissolved in $1 \mathrm{~mL}$ of DMF. $10 \mathrm{mg}$ of $\mathrm{PdO} / \mathrm{BaSO}_{4}$ catalyst was added to the solution and the reaction vessel was connected to the tritium manifold. When the vessel and all tubing had been evacuated, tritium gas was liberated from the tritium reservoir containing uranium tritide by heating, and $555 \mathrm{GBq}$ (15 Ci) of it was introduced into the reaction vessel. The reaction mixture was stirred at room temperature for 60 min and after the solution was frozen and the unreacted tritium gas was absorbed onto pyrophoric uranium. The catalyst was filtered on a Whatmann GF/C filter and the labil tritiums were removed by repeated vacuum evaporation of ethanol-water (1:1) solution of the tritiated crude product. Total radioactivity was $3.69 \mathrm{GBq}(100 \mathrm{mCi})$. The crude peptide was purified by RP-HPLC on Vydac 218TP1010 (250 x 10 mm) using linear gradient elution from $15 \%$ - 45\% of acetonitrile $(0.08 \%$ TFA) in water $(0.1 \%$ TFA) within $30 \mathrm{~min}$ at a flow rate of $3 \mathrm{~mL} / \mathrm{min}$ with $\mathrm{UV}$ detection at $220 \mathrm{~nm}$. The radioactive purity of the final product was found to be $>98 \%$ using analytical RP-HPLC on Vydac 218TP54 (250 x $4.6 \mathrm{~mm})$ column, gradient elution: $15 \%$ - $45 \%$ of acetonitrile $\left(0.08 \%\right.$ TFA) in water $\left(0.1 \%\right.$ TFA) within $30 \mathrm{~min}$ at a flow rate of $1 \mathrm{~cm}^{3} / \mathrm{min}$ with UV detection at $220 \mathrm{~nm}$, retention time is $10.60 \mathrm{~min}, \mathrm{k}^{\prime}=2.38$ ). Specific radioactivity was estimated by calibration curve prepared with standard peptide and the radioactivity was measured by liquid scintillation counting. The specific radioactivity was $1.29 \mathrm{TBq} / \mathrm{mmol}(35.0$ $\mathrm{Ci} / \mathrm{mmol})$. Storage: in liquid nitrogen.

H-(R)- $\boldsymbol{\beta}^{2} \mathbf{h V a l - T y r - I l e - A i a -}{ }^{3} \mathbf{H}$-Nva-Phe-OH $\left({ }^{3} \mathbf{H}\right.$-IVDE77). $3 \mathrm{mg}$ of H-(R)- $\beta^{2} \mathrm{hVal}$-Tyr-IleAia-Pra-Phe-OH was dissolved in $1 \mathrm{~mL}$ of DMF containing $2 \mu \mathrm{L}$ TEA. $10 \mathrm{mg}$ of $\mathrm{PdO} / \mathrm{BaSO}_{4}$ catalyst was added to the solution and the reaction vessel was connected to the tritium manifold. The tritiation was made as above. The reaction time was $84 \mathrm{~min}$. The total radioactivity was 5.0 GBq. The crude peptide was purified by RP-HPLC on Atlantic C18 (150 x $3.9 \mathrm{~mm})$ using linear 
gradient elution from $20 \%$ - $40 \%$ of acetonitrile ( $0.08 \%$ TFA) in water $(0.1 \%$ TFA) within 30 min at a flow rate of $1 \mathrm{~mL} / \mathrm{min}$ with UV detection at $220 \mathrm{~nm}$ and radioactive detection. Retention time was $21.5 \mathrm{~min}$. Specific radioactivity was $0.9 \mathrm{TBq} / \mathrm{mmol}$. The purity of the final product was $>98 \%$. Store at $-80^{\circ} \mathrm{C}$.

${ }^{3}$ H-neuromedin-N (Lys-Ile- ${ }^{3}$ HPro-Tyr-Ile-Leu-OH). $3 \mathrm{mg}$ of Lys-Ile- $\Delta$ Pro-Tyr-Ile-Leu-OH was dissolved in $1 \mathrm{~mL}$ of DMF and $10 \mathrm{mg}$ of $\mathrm{PdO} / \mathrm{BaSO}_{4}$ catalyst and $1 \mu \mathrm{L}$ of TEA were added to the precursor solution in the reaction vessel. Tritium gas $370 \mathrm{GBq}(10 \mathrm{Ci})$ was introduced to the reaction mixture and it was stirred by magnetic stirrer for 1 hour at room temperature. The catalyst was filtered through Whatmann GF/C glass fiber filter and washed with ethanol several times. The labile tritium was removed by repeated evaporation with ethanol-water (1:1). The total radioactivity of the crude peptide was $1.75 \mathrm{GBq}(47.3 \mathrm{mCi})$. The crude peptide was purified by RP-HPLC using analytical column (Atlantis C-18) and linear gradient of the elution system from $20 \%$ up to $40 \%$ acetonitrile with $0.08 \%$ TFA in water with $1 \%$ TFA over 25 min at a flow rate of $1 \mathrm{ml} / \mathrm{min}$ and $216 \mathrm{~nm}$. Retention time was $10.0 \mathrm{~min}$. The specific radioactivity was determined to be $0.6 \mathrm{TBq} / \mathrm{mmol}(16 \mathrm{Ci} / \mathrm{mmol})$. The radioligand was stored at $-80{ }^{\circ} \mathrm{C}$.

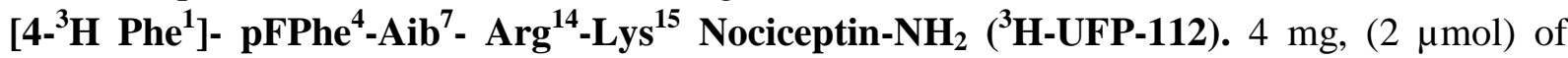
pIPhe $^{1} \mathrm{pFPhe}^{4}-\mathrm{Aib}^{7}-\mathrm{Arg}^{14}$-Lys ${ }^{15}$ Nociceptin- $\mathrm{NH}_{2}$ precursor peptide was dissolved in $1 \mathrm{~mL}$ of DMF and $2 \mathrm{mg}$ of $\mathrm{PdO}(85 \% \mathrm{Pd}$ ) catalyst (Merck) and $1 \mu \mathrm{L}$ of $\mathrm{N}$ - diisopropylethylamine were added to the precursor solution in the reaction vessel. The vessel was connected to the tritium manifold. Tritium gas $370 \mathrm{GBq}(10 \mathrm{Ci})$ was introduced to the reaction mixture and it was stirred by a magnetic stirrer for 1 hour at room temperature. The unreacted tritium gas was absorbed by pyrophoric uranium. The catalyst was filtered through Whatmann GF/C glass fiber filter and washed with ethanol several times. The labile tritium was removed by repeated evaporation with ethanol-water (1:1). The total activity of the crude peptide was $0.52 \mathrm{GBq}(14 \mathrm{mCi})$. The crude labelled peptide was purified by RP-HPLC on Atlantic C18 column using linear gradient of the eluent system from $5 \%$ up to $20 \%$ acetonitrile with $0.08 \%$ TFA in water with $1 \%$ TFA over 20 min at a flow rate of $1 \mathrm{~mL} / \mathrm{min}$ and $216 \mathrm{~nm}$. Retention time was $10.1 \mathrm{~min}$. The specific radioactivity was determined to be $0.73 \mathrm{TBq} / \mathrm{mmol}(19.8 \mathrm{Ci} / \mathrm{mmol})$. The radioligand was stored in liquid nitrogen.

H-Arg- ${ }^{3}$ HPro-Lys- ${ }^{3}$ HProGIn-GIn-Phe-Phe-Gly-Leu-Nle-NH ${ }_{2}\left({ }^{3} \mathbf{H}_{-N l e}{ }^{11}\right.$-Substance-P). $3 \mathrm{mg}$ of $\Delta \mathrm{Pro}^{2,4} \mathrm{Nle}^{11}$-SP $(2 \mu \mathrm{mol})$ was dissolved in $1 \mathrm{~mL}$ of $\mathrm{DMF}$ and $10 \mathrm{mg}$ of $\mathrm{PdO} / \mathrm{BaSO}_{4}$ catalyst was added to the solution in the reaction vessel. The vessel was connected to the tritiation manifold. Tritium gas $370 \mathrm{GBq}(10 \mathrm{Ci})$ was introduced to the reaction mixture and it was stirred for $90 \mathrm{~min}$ at room temperature. The catalyst was filtered through Whatmann GF/C fiber filter. The labile tritium was removed by repeated evaporation with ethanol-water (1:1). The total radioactivity of the crude peptide was $1.27 \mathrm{GBq}(34.48 \mathrm{mCi})$. The labeled peptide was purified by HPLC on Altima $\mathrm{C}_{18}, 5 \mu \mathrm{m}(3.9 \times 150 \mathrm{~mm})$ with linear gradient of the elution system from 20 $\%$ up to $60 \%$ acetonitrile with $0.08 \%$ TFA in water with $1 \%$ TFA over 25 min at a flow rate of 1 $\mathrm{mL} / \mathrm{min}$ and $216 \mathrm{~nm}$. Retention time was $9.3 \mathrm{~min}$. The specific radioactivity was determined to 
be $0.73 \mathrm{TBq} / \mathrm{mmol}(22.4 \mathrm{Ci} / \mathrm{mmol})$. The radioligand was stored in liquid nitrogen in $37 \mathrm{MBq} / \mathrm{mL}$ concentration.

\section{Acknowledgements}

We are grateful to Prof. Ferenc Fülöp (Institute of Pharmaceutical Chemistry, University of Szeged) for 2-aminocyclopentenecarboxylic acid and 2-aminocyclohexenecarboxylic acid; to Isabelle Van den Eynde (Department of Organic Chemistry, Vrije Universiteit Brussel, Belgium) for angiotensin IV precursor peptides, to Patrycija Kleczkowska (Mossakowski Medical Research Center of Polish Academy of Sciences, Warsaw, Poland.) for neuromedin-N precursor, to Remo Guarreni (University of Ferrara, Italy) for UFP-112 precursor.

\section{References}

1. Saljoughian, M.; Williams, P. G. Curr. Pharm. Des. 2000, 6, 1029.

2. Tóth, G.; Lovas, S.; Ötvös F. In Molecular Biology, Neuropeptide Protocols; Irvine, G. B.; Williams, C. H., Eds.; Humana Press: Totowa, NJ. 1997; Vol. 73, p 219.

3. Tömböly, C.; Dixit, R.; Lengyel, I.; Borsodi, A.; Tóth, G. J. Labelled Compd. Radiopharm. 2001, 44, 355.

4. Tömböly, C.; Péter, A.; Tóth, G. Peptides 2002, 23, 1571.

5. Spetea, M.; Monory, K.; Tömböly, C.; Tóth, G.; Tzavara, E.; Benyhe, S.; Hanoune, J.; Borsodi, A. Biochem. Biophys. Res. Commun. 1998, 250, 720.

6. Monory, K.; Bourin, M.C.; Spetea, M.; Tömböly, C.; Tóth, G.; Matthes, H. W.; Kieffer, B. L.; Hanoune, J.; Borsodi, A. Eur. J. Neurosci. 2000, 12, 577.

7. Keresztes, A.; Szűcs, M.; Borics, A.; Kövér, E. K.; Forró, E.; Fülöp, F.; Tömböly, C.; Péter, A.; Páhi, A.; Fábian, G.; Murányi, M.; Tóth, G. J. Med. Chem. 2008, 51, 4270.

8. Keresztes, A.; Tóth, G.; Fülöp, F.; Szücs, M. Peptides 2006, 27, 3315.

9. Forró, E.; Fülöp, F. Tetrahedron: Assymmetry 2004, i, 2875.

10. Keresztes, A.; Birkás, E.; Páhi, A.; Tóth, G.; Bakota, L.; Gulya, K.; Szücs M. Peptides, 2011, 32, 722.

11. Szemenyei, E.; Tóth, G. J. Labelled Compd. Radiopharm. 2007, 50, 1148.

12. Lukaszuk, A.; Demaegdt H.; Szemenyei E.; Tóth, G.; Tymecka D.; Misicka, A.; Karoyan, P.; Vanderheyden, P.; Vanquelin, G.; Tourwé, D. J. Med. Chem. 2008, 51, 2291.

13. Demaegdt, H.; Gard, P.; De Backer, J-P.; Lukaszuk, A.; Szemenyei, E.; Tóth, G.; Tourwé, D.; Vauquelin, G. Mol. Cell. Endocrin. 2011, 339, 34.

14. Chansel, D.; Czekalski, S.; Vandermeersch, S.; Ruffet, E.; Fournie-Zaluski, M. C.; Ardaillou, R. Am. J. Physiol. 1998, 275, F535. 
15. Lukaszuk, A.; Demaegdt, H.; Feytens, D.; Vanderheyden, P.; Vauquelin, G.; Tourwé, D. J. Med. Chem. 2009, 52, 5612.

16. Van den Eynde, I.; Lukaszuk, A.; Buysee, K.; Demaegdt, H.; Karoyan, P.; Vauquelin, G.; Keresztes, A.; Tóth G.; Péter, A.; Tourwé, D. Proceedings of the $31^{\text {th }}$ European Peptide Symposium, Lebl, M.; Meldal, M.; Jensen, K.J.; Hoeg-Jensen, T. Eds.; European Peptide Society 2010, p138.

17. Minamino N.; Kangawa, K.; Matsuo, H. Biochem. Biophys. Res. Commun. 1984, 122, 542.

18. Rizzi, A.; Spagnolo, B.; Wainford, R.D.; Fischetti, C.; Guerrini, R.; Marzola, G.; Baltisserotto, A.; Salvadori, S.; Regoli, D.; Kapusta, D.R.; Calo, G. Peptides 2007, 28, 753..

19. Almeida, T. A.; Rojo, J.; Nieto, P. M.; Pinto, F. M.; Hernandez, M.; Martin, J. D.; Candenas, M. L. Curr. Med. Chem. 2002, 11, 2045.

20. Park, C. H; Massari, V. J.; Quirion, R.; Shults, C. W.; O’Donohue, T. L. Peptides 1984, 5, 833.

21. Bienert, M.; Klauschenz, E.; Erlich, S.; Katzwinkel, S.; Niedrich, H.; Tóth, G.; Teplán, I. J. Labelled Comp. Radiopharm. 1979, 16, 673.

22. Botros, M.; Hallberg, M.; Johansson, T.; Zhou, Q.; Lindeberg, G.; Frandberg, P.; Tömböly, C.; Tóth, G.; Le Greves, P.; Nyberg, F. Peptides 2006, 27, 753. 